\title{
Approaches to Defining a Television Format as one of Intellectual Property Law objects: Ukrainian and Foreign Experiences
}

\author{
Alena Sylkina ${ }^{1}$
}

\begin{abstract}
In this article the author analyzes theoretical approaches which were formulated due to the appearance of complex objects of Intellectual Property Law. The attention is concentrated on the analysis of concepts that investigate the legal nature of a television format. The author considers that it is necessary to differentiate a positive approach which recognizes that a format is an object of Intellectual Property Law and negative approach which denies the possibility of television formats protection.

Through the method of comparison between the scientific doctrine and judicial practice in the countries of the Romano-Germanic and Anglo-Saxon legal systems, the author classifies concepts to be developed by theoretic community. Thus, negative approach of the Romano-Germanic Legal system countries is confirmed by normative legal acts which relate to the ideas, methods and concepts. Representatives of the Anglo-Saxon Legal system make it impossible to protect a format within the doctrines: "scene a fair", "idea \expression", "merger", etc. The author prefers the positive approach which is divided into the following concepts of the analysis of a format: as a dramatic work (according to Copyright Law), as a hybrid object, as a synthetic object, as a compilation, as a complex object of IP Law.

The author gives the definition to a television format, explains its legal nature, and views a format as one related to the concept of complex Intellectual Property Law objects. She analyzes judicial practice which has developed in Ukraine and abroad. Taking into consideration the fact that relations which are connected with the distribution of a format have not only national, but also global character, it is important to unify the given approaches and to use them in legislature. It is relevant to enhance and standardize the legislation in the television field which would contribute to the development of contractual relations between the countries.
\end{abstract}

Keywords: tv-format, television format, complex object, bybrid object, intellectual property.

\section{Introduction}

Intellectual Property Law has been replenishing with new sophisticated results of creative activity. Complex Intellectual Property objects have been rarely researched in the legal literature; however, there was captured the attention to a phenomenon of combined works, non-uniform in their structure. One of such objects is the television format. Therefore nowadays it is relevant to identify the place of a format among other similar works, its stipulation at the legislative level and resolving practical tasks, which arise from numerous violations of the rights for a format. It is expedient to analyze the theoretical concepts and provisions of the civil legislation that is elaborated by theoreticians and to clarify the legal nature of not only each element of a television format, but the whole complex object. 
The Intellectual Property Law objects analysis allows us to mark out their obvious features and to group them respectively. In Intellectual Property Law the objects are usually conditionally divided into four groups: the first group contains of copyrighted works - literary and works of art, computer programs, compilations of data, performances, soundtracks, broadcasts (programs). Objects of industrial property are included into the second group: inventions, utility models, industrial designs. Plant varieties and breeds of animals that are equated to industrial property objects belong to the third group. The fourth group includes the commercial (business) names, trademarks (signs of goods or services), geographical indications. [11] The TRIPS Agreement states that, for the purposes of the Agreement, the term "intellectual property" refers to all categories of intellectual property that are the subject of Sections 1 through 7 of Part II of the TRIPS Agreement, namely, copyright and related rights, trademarks, geographical indications, industrial designs, patents, layout-designs (topographies) of integrated circuits and undisclosed information. [12]

However today in civil turnover there are created new complex objects which demand stipulation within the legal framework, which are: television formats, video games, multimedia products, long-reads, quest rooms, etc. Outside of the above mentioned division there continue to remain numerous objects which have the mixed legal nature. In order to define the place of a television format among Intellectual Property Law objects it is important to investigate its legal essence, elements and features.

On the legislative level of different countries of the world such concept as "the right for a television format", is absent per se. For the purpose of ensuring the protection for such a vulnerable object as a television format, and for enabling the opportunity of stipulating this legal concept in normative legal acts, it is necessary to analyze other objects of intellectual property law which are similar by nature. It is important to classify the existing approaches and concepts in a format as an object of private law relations.

In my opinion, "the television format" is a complex object of Intellectual Property Law which consists of a unique combination of variable elements (The Bible, the scenario, music, images, a know-how, a trademark, etc.) which provide its identification, distinguish from other formats of audiovisual works, help to adapt the original television program on any territory, and are embodied in audiovisual work (the television program). By definition it is clear that the television format can hardly refer to one of the Intellectual Property Law objects groups as it is a combination of diverse elements some of which fall under the protection of Intellectual Property Law, and some do not. Opponents of television formats' legal protection refer to Article 2 of The WIPO Copyright Treaty (WCT) which states that "Copyright protection extends to expressions and not to ideas, procedures, methods of operation or mathematical concepts as such." This is virtually the same as the clarification included in Article 9.2 of the TRIPS Agreement. [12] As legal protection extends only to a form of expression of the work and does not extend to any ideas, theories, the principles, methods, procedures, processes, systems, ways, concepts, discoveries even if they are expressed, described, explained, illustrated in the work. There is a question: What is a format - an idea, which is not protected, or an object, which needs the legal protection? To answer this question in this article there is carried out comparative analysis of both theoretical and practical regulations concerning Intellectual Property Law objects in different countries. There are 
investigated concepts that prove the existence of complex IP Law objects, and came to the conclusion as to which of them is the optimal for the purposes of legal relations.

The world theoretic community has elaborated several approaches through which, it is possible to analyze a television format. We suggest dividing these approaches into negative, those that do not recognize a format of the complex object of IP Law, and positive through which there was achieved the protection of a television format in practice. Normative legal acts of the Romano-Germanic system countries and judicial precedents of the Anglo - Saxon system countries are flexible, the acquired judicial practice both denies and on the contrary, provides protection of formats of television programs. It is important to pay attention to the "core" of the made decisions regarding the means of protecting such vulnerable objects of IP Law as TV formats and to unify different approaches of theoreticians.

\section{Methodology}

The author elaborates on the issue of determining the place of a format among similar Intellectual Property Law objects. For the purposes of resolving this objective the author has used general scientific methods which encounter: methods of analysis and induction. The author generalizes the existing approaches which provide analysis for the legal nature of a television format by means of comparative-historical method. In the article there are classified all existing theoretical concepts by two criteria: positive (which recognizes a format as an object of the IP Law) and negative (which deny the possibility of a format protection). By analogy to similar objects in Intellectual Property Law, the author provides the concept of a television format and refers it to complex objects of IP Law. Applying the systemic analysis of already existing concepts created by theoreticians, the author has established connections between them, characterized the features which had been earlier identified by researchers, in order to make a grounded evaluation of a format that needs to be stipulated in the legal realm.

\section{Foreign Experience of the negative approach (objection of the television format protection)}

The first approach (negative) is the denial of format recognition as an Intellectual Property Law object. In denying protection for formats the supporters of this approach in the Romano-Germanic Legal system countries refer to the relevant normative legal acts. Scientists do not refer formats to the first group of objects of the IP Law because it cannot be recognized as subject to Copyright Law. Supporters of the negative approach refer formats to methods, concepts and ideas. Thus 103 countries have ratified the World convention on copyright (Geneva 1996) where in the Article 2 it is specified that the sphere of copyright protection extends to the form of expression, but not to the ideas, procedures, work methods, mathematical concepts per se. Thus, scientists who consider a format to be only an idea or a concept deny the possibility of its protection. It is difficult to agree with such a point of view minding that it is impossible to consider a format as a concept or a idea This object consists of various elements, the majority of which are protected by copyright, and their unique combination in a television format 
should be considered as a complex object. Some of the elements fall not only under the Copyright Law, but also the Law of Industrial Property. Therefore it is relevant to unify the legal regime of a new object referring it to complex objects.

In the countries of Anglo-Saxon legal system (the USA, Great Britain) restrictions for protection of television programs formats are introduced due to the following doctrines: (1) dichotomy of idea/expression; (2) scènes à faire, or "scenes which need to be made"; and (3) doctrine of a merger. The USA is the leader in generating and selling formats, however as well as in European countries it demonstrates contradictory judicial practice of television formats' protection. The doctrine of "idea/expression" (idea/expression) comes down to the understanding that the description of certain actions that have utilitarian value and further are carried out by a third party - are not protected by copyright. The content of "Scènes à faire" doctrine is "scenes which need to be made" for a certain genre. In other words some scenes naturally characterize certain genres and therefore are not protected by copyright. For example, the scene of awarding in a television program with talents competition is patrimonial; nobody can ban an awards ceremony in other programs. This doctrine enshrines the provision that no author of a format for television program can have the uniform right to use patrimonial scenes.

The doctrine of merger is when it is difficult to divide an idea and its expression because the idea is simple and is expressed in a limited amount of ways. Thus an idea and its expressions merge in such cases. A competitive television program would be an example where there are several rounds and participants are excluded in turns. No single program author can forbid creating programs with such a simple similar expression of an idea.

We consider that doctrines legitimately limit the protection of television formats, but do not preclude the possibility of such protection in general. None of the doctrines forbids proving the originality of expression of the idea and the uniqueness of elements' combination in a format that guarantees the protection of formats. In certain cases, when a court cannot make the decision in defining the degree of originality of an idea expression, the so-called three-step test of "abstractions filtration" is applied. The first step of the test is abstraction: the court has to estimate the level of similarity between two works, whether the similarity between works consists of an idea only or the idea of a certain work is more developed and complex. The second step of the test - "filtration": after the court establishes similarity of works, it has to filter materials which are not protected by copyright, including elements from public domain.

Lawyers in the USA emphasize that these doctrines significantly limit the possibility of protection of a format by means of Copyright Law, however the format can be potentially protected as a "compilation". While these doctrines do severely limit the possibility of copyright protection, a format may still be potentially protected as a compilation. As it was state by the court in a decision Pros $v$. Joes regarding the reality show "although stock concepts and 'scènes à faire' are unprotectable under Copyright Law in and of themselves, their selection, coordination, and arrangement can be protectable, to extent that it reflects particular expression of ideas." [7]

Judicial practice in Great Britain is also ambiguous, the negative approach is implemented in the judgment on "Broadcasting Corporation of New Zealand" [6] of July 18, 1989. The court refused to grant protection to a television format on the following grounds: 1) the absence of a copyrightable subject matter in the claim, of an allegation of 
copyright infringement in a format 2) the elements of a dramatic work should have sufficient unity to bear the title of a " television program format" 3) the scenario expressed only the general thought and concept, and therefore cannot be protected by Copyright Law. However, it is necessary to notice that in this case several judges disagreed with majority opinions. J. Galen expressed the dissenting opinion that in this case the judges investigated an interpretation of the "scenario" concept, where it was necessary to recognize the fact of creation of a dramatic work - television format. Therefore, one group of judges does not recognize a format as a Copyright Law object at all, and the other part of a judiciary board refers a format to Copyright Law objects as dramatic work. We consider that both positions are imperfect, they narrow the essence of a format as a complex IP Law object. The format consists of diverse elements, and therefore the protection also has to be complex. Limiting the protection only to Copyright Law means is false.

It is difficult to agree with negative approach which peremptorily denies the possibility of formats protection due to the fact that on the international arena there is a recent trend of recognition of a format as an Intellectual Property Law object not only by nongovernmental world organizations, but also by the Supreme Courts of the different countries. This is discussed in more detail further. Moreover the reason for judicial refusals of granting protection to TV formats is often rather weak argumentation of plaintiffs in defending copyrights for formats.

\section{Positive approach recognizing formats as IP Law objects: national and international experiences.}

The complexity of a television format demands the formation of the new unified model of a legal regime of this object. The second approach (positive) lies in recognition of a format as an Intellectual Property Law object. The positive approach differs as to its concepts, theoreticians recognize a format: as the Copyright Law object, as a hybrid object, as a synthetic object, and as a complex object. These concepts have similarities as all of them pursue one aim - recognition of the existence of a format in Intellectual Property Law. However it is expedient to unify concepts, to analyze their defining features, and to provide regulation of the most efficient one at the legislative level. We will analyze "pro et contra" of each concept to elaborate suggestions of enhancement for national and international legislation.

The first positive attempts of protection of a format began in the Anglo-Saxon legal system (the USA, Great Britain). The format repeatedly was recognized as a Copyright Law object. Until 1978 in the USA there was in force "The law of the ideas". According to the law unpublished works were protected by the state at the legislative level. This law was written in the 1950th years in California, at the time when the majority of jurisdictions of the world were adhering to the view that "ideas are free as air" and are not protected. This law protected any "product of mind" calling it "exclusive property". In its decision of 1970 on "Fink v Goodson Todman Enterprises" [5]one of the US courts came to a conclusion that television formats can be granted Copyright Law protection in countries of Common Law legal system. 
"The claimant's material is what it is possible to call partial (but essential) development of completely fulfilled subject of television series. Professor of copyright Nimmer characterizes similar material as work "core". It is what writers call "the idea of a backbone" (spine idea) or "the developed idea" (elaborated idea). That is the court defined a format as "ridge" of the movie, series or program on which everything keeps. Such a "structural spine" is apparent in the "Branded" series. Court established the meaning plaintiff's "spine" idea is composed as indicated more fully in the fact recital: (1) the basic theme that one whose courage has been put in doubt to himself and others will act to remove that doubt; (2) a detailed exposition (through the combination of the presentation and pilot script) of the back story, the hero's military experience wherein his courage was tested; (3) the plots for 15 of an estimated 39 weekly episodes; and (4) the portrayal techniques of (a) introducing the back story through a dream sequence in the first episode, (b) building and re-focusing attention upon it by flashbacks in succeeding episodes, (c) using the signature and talisman devices to keep the audience reminded of the central theme, (d) tying the surface plots of the individual episodes into and having them play upon the back story, and (e) making music a significant feature of the series by having it create atmosphere or tell part of the story. To sum up, it is a combination of factual features and portrayal techniques. [5]

Having taken the claimant's arguments into account the court concluded that "the expression of dramatic character in the format is sufficient for the standards of protection. Not all elements of this work can be protected, but the majority of elements are the essence of a format". The court considers that the amounts of elements which are subject to protection, their combination are sufficient to protect a format in general. After cancellation of this law, unpublished formats became more difficult to protect, however, the big percentage of formats is protected by copyright in Common Law countries until now.

In judicial practice there quite often prevails the concept of recognition of a format as dramatic work. Protection of a format thus fell under the regulation of copyright legislation. Thus in the case «Banner v Endemol» of 2017. [2] The Supreme Court of Great Britain stated that each described episode of the television program in a format should probably be protected by copyright as a dramatic work. Therefore copyrights are deemed to be infringed if someone without the permission of the author reproduced this episode. However, lawyers of the Anglo-Saxon system have expressed different opinions on this issue. Theoreticians Blair and Altoff supported the Supreme Court decision that formats need to be protected as dramatic works of an authorship if they contain enough of distinctive features that a specific television program could be reproduced to others in a recognizable form. Another point of view was expressed by Morgan and Smith that this judgment is a warning to developers of television formats due to the fact that the court only recognized the protection of formats by Copyright Law. [1]

In Canada the concept that a format can be classified as a dramatic work of Copyright Law is also supported. In the case "Kantet $v$ Grant", the format of a program for children could be protected on the grounds that the structure of the program was accurately outlined. The court emphasized that there has to be "essential" reproduction of the program in a format because it is a high-quality and quantitative work, with consideration of a plot, topic, dialogues, the general mood, scenes, sequence, and a trademark. The 
standard is that, the average viewer can recognize in a certain program the copy of another which is appropriated in violation of copyrights".

This concept is not inherent to the Romano-Germanic legal system countries where courts and the legislators do not refer a format to Copyright Law objects by analogy with dramatic works. It is reasonable to agree with this opinion minding that even though both - formats and dramatic works are complex objects, there are however essential distinctions between them. Dramatic works are simultaneously related to two types of artistic works - theater and literature (regulations is provided specifically through Copyright Law). In turn the format belongs to cinematic art, particularly the creation of audiovisual works - television programs. And it comprises of such elements as copyrighted works, industrial property objects, trade marks, know-how and right for commercial name.

One of the concepts to which some theoreticians suggest to refer a format is the concept of hybrid objects. The first to research on "legal hybrids" between Copyright Law and Patent Law in 1994 was Jerome Reykhman, a law professor from USA. The author described the hybridization of Intellectual Property Law in his work which was connected "to the interdependent nature of creative and innovative processes. For example, brothers Wright developed their own methods of flight and forbade their use by others through the patent legislation. When J.K. Rowling wrote the book "Harry Potter", the author was protected from plagiarism by the legislation on copyright. However, there is a question of what to do with such objects as software or car design when they include both utilitarian and creative elements. It is clear that the line of demarcation of the protection of certain objects by conventions is limited. The Bern convention - protects only Copyright Law objects, the Paris Convention only protects Industrial Property objects, the Madrid Convention - trademarks. A large number of socalled hybrid objects are beyond the measures. Thus in France courts consider video games as the complex object consisting of different elements. And the World Intellectual Property Organization, approving judgments, concurrently defines the status of games as "hybrid objects" for the purpose of rendering legal protection to them. [10]

Russian theoreticians, the majority of whom are representatives of Media Law, prove hybrid nature of a format. Novikova A. A. in her article claims that the defining feture of a television format is its hybrid nature and aspiration to reformatting. According to the researcher's conclusions, any format contains elements of several genres which are combined into one solid object. [9]However it is seems impossible to come to the conclusion that a format is a combination of elements of different genres. A genre is a type of the work which reflects its stylistic, formal and substantial features. From the legal point of view, a format in contains not genres but embodies a combination of elements which fall under a different legal regime therefore its defining feature is its complexity as an Intellectual Property Law object.

Among the models offered by theoreticians there is the concept of "synthesized" (synthetic) objects of legal regulation which is developed by Russian scientists. To this category V. Panteleev and V. Naumov refer all the objects which are self-sufficient objects of legal regulation and are already protected by the means of law. However as a result of the combination of these objects there appears an absolutely new object that has special value and can only exist as a result of all its components' a combination. 
These objects encounter songs as a "synthesized" object of legal regulation where there are combined copyrights for music, text and related rights for images, placement of certain means of individualization. It is possible to refer a television format to this model due to the fact that it also combines diverse elements, such as scenario, "bible", images, know-how, trademark etc.

However concepts of "a synthetic object" and "legal hybrids" are not accepted by legislators in foreign countries during the elaboration of normative legal acts. This language is not inherent to the world theoretical community. These concepts are more proved at the theoretical level than are met in practice. We consider that it is more expedient to apply the widely used category of a "complex object" which is defined not only by theoretical authors, but is also stipulated on the legislative level of many countries and corresponds to features inherent to a television format. However it is obvious that having different names the above-mentioned concepts are identical regarding their contents. All of them have the only purpose - to provide legal regulation "to the objects which elements are mixed in their legal nature. In modern conditions there are complex objects which have non-uniform legal regulation as they comprise of various elements.

Along with the trend of expanding the number of specific legal regimes it is necessary to emphasize on the opposite trend - the unification of such regimes. Nowadays there takes place the unification of legal regulation in different countries, but the trend of legislation unification in Intellectual Property domain has another interesting manifestation which remains beyond attention of researchers - that is convergence of legal regimes of various objects. The evidence to this is the emergence at the international level of the document general in its nature - "Agreement on Trade Related Aspects of Intellectual Property Rights" (TRIPS). This trend is defined, of course, not by wishes of certain theorists, but by objective requirements of society: polytypic results of intellectual activity are often used in combination and applying to them mutually conflicting models generates confusion in practice. There exists a similar situation in other areas of Intellectual Property Law: the complex structure is inherent to most various results of intellectual activity such as movies and other audiovisual works, computer programs, databases, websites etc. It is obvious that for mentioned cases it is necessary to elaborate specific rules allowing to work with such objects as whole, not as with a set of separate results of intellectual activity. This includes the stipulation of the right for a solid object, its exploitation without the need to coordinate with every the person that in a certain way participated in creation of an object, the disposal of economic rights for such an object, its legal protection etc. This concept reflects the context of such objects as formats and guarantees their legal regime.

In legislations of many countries special provisions apply to audiovisual works. In particular: "Cinematic works belong to complex works which are protected as separately in themselves or as combined works, irrespective of a creative contribution of different persons to their creation." (Article 20 of the Law of Argentina "On Literary and Artistic Property", the Law of Great Britain of Industrial designs and Patents of 1988 (Paragraph 2 of Article 10), the Intellectual Property Code of France (SRG), 113 7; The Law of Spain "On Intellectual Property", Article 87). 
Upon the analysis of foreign countries' legislation (Russia, France, Great Britain, the USA etc.) it is possible to conclude that despite the divergence in use of terminology in the concepts, all of them provide a possibility of protection of works which incorporate various elements and are created by efforts of different subjects of Copyright Law. It is reasonable to implement these concepts into the national legislation for the purposes of harmonizing Intellectual Property relations with those of other countries.

The Ukrainian legislator operates on the concept of "collective work", but does not define a "complex work", however these concepts are different in their meaning. In the Law of Ukraine "On Copyright and Related Rights" the article 19 affirms copyright protection for compilations and other constituent works. This leads to the conclusion that a constituent work is only an assembly, a certain compilation of works (parts of works) or other data, selection and arrangement of which is the result of creative activity and systematization. The specificity of complex works is emphasized in the research of O. Zhylinkova who defines their features, - this is the work in which: 1) works of two or more types of art are combined (diversity of copyrighted objects); 2) each of the parts of such a work was created for the purpose of creation of the complex work; 3) none of the parts of the work is superior in relation to others; 4) parts of the work can be used both together, and separately from other parts of the work, that is to have independent value.[14] In another article the author refers a television format to complex works of Intellectual Property Law. [13] Unfortunately, in the legislation of the majority of the countries of the world this concept is not stipulated, however, we consider that this concept best reflects the essential contents of a format.

The necessity of development of the general regulation models for such objects has become obvious upon the emerging of movies. However in the modern society the presence of complex IP structures is rather a rule than an exception. In this regard it is important to recognize the extremely timely emergence of a complex object concept in Civil Law. Reflecting over what is a complex intellectual product Professor V.A. Dozortsev characterized it as multilayered, i.e. as existsting as a whole, including all elements, without any of which it is non-existent, although the majority of elements can be used independently or separately. [4]

In the national legislation there exists a category of a "complex item" (Article 188 of the Civil Code of Ukraine), but the concept "complex object", concerning Intellectual Property Law objects is absent. As a result there exists the problem of referring a format to Intellectual Property Law objects. In Ukrainian legislation there are no categories which would allow the appropriate definition for a formats' legal nature. Current legislation does not shed light on complex objects at all. "De facto" they exist, however "de jure" they are left without appropriate protection and legislative representation. We consider that it is reasonable to promote the concept of complex IP Law objects on the national and international legal levels. This concept would compensate the existing void in legislative regulation.

\section{Results}

Taking into account the imperfection of legislation and the presence of virtually opposite approaches of theoreticians, for the purpose of legal definiteness, we consider it 
necessary to define the features of a television format which distinguish it from others objects:

1) It is a complex Intellectual Property Law object which consists of a unique combination of diverse, variable elements (a bible, scenario, scripts, music, images, know-how, a trademark etc.)

2) The elements are protected by different normative legal acts (Copyright Law, Industrial Property Law, Commercial Law etc.)

3) Teleformat provides identification of a television program, distinguishes it from other audiovisual works.

4) The bible of a format helps licensees to adopt the original television program for any territory. This generates processes which are specific for formats - adaptation, localization and globalization are inherent to formats (a possibility of reproduction of a complex creative activity result on the territory of any country).

5) It is embodied in a completed result of Intellectual Property Law - an audiovisual work (television program).

Having had analyzed both of the approaches we came to a conclusion that the positive concepts which recognize the protection of a format are more rational. In judicial practice of the Romano-Germanic system, Ukraine being among them, the preference is given to the positive approach which recognizes a format as an object of Intellectual Property Law. In 2003 the Supreme Court of Germany in the "Sendeformat" case determined that "the format of the television program is a set of its characteristic features capable of serving as a general template which forms each separate program, making it possible for the public to identify the program, irrespective of its changeable contents, as a part of a series of television programs" and has satisfied the claim. Also the decision of the Supreme Court of the Netherlands of 16.04.2004 in the "Survive! vs. Big Brother" [8] case was positive. The court came to a conclusion that upon the comparison of 12 elements of both programs, not all elements can satisfy the originality criteria. However, the court rendered the decision that the combination of these elements is original and is sufficiently complex to conform to the requirements of copyright protection. On July 27, 2017 the Supreme Court of Italy (Corte di to the Kassaziyena) confirmed that television formats can be protected according to the Italian legislation on copyright (Legge 633/1941) and the grounds of such protection is found. The court reminded that the Italian copyright act does not contain the term "format", but according to the document 66/1994 SIAE, the work can be qualified as "format" in case there are demonstrated: the corresponding elements, logical and theme connections (consisting of heading, the main structure, scenography and the fixed symbols). The resonant case in Ukraine was the dispute between New Channel and its program «Revison» and 1+1 Channel with their show "Inspector Freymouth". On February 17, 2016 the Supreme Court of Ukraine has satisfied the claim of New Channel therefore protecting intellectual property rights for a television product. The court listed the copied elements of the television program: the host's image, nature of the unexpected checking of institutions, criteria of the checking. In fact the court has enlisted the elements that are included into the bibles of a format and are subject to protection by Copyright Law. However in its decision the national court does not apply the category a television format. 


\section{Conclusions}

Classifying all the existing concepts by criteria of protection positivity and negativity we came to the conclusion that both approaches are inherent to both Romano-Germanic and Common Law legal systems countries. Nowadays the denial of the possibility of formats' protection is caused by peculiarities of legislative systems. Thus the Romano-Germanic legal system countries have developed the negative concepts deriving from provisions of national normative legal acts which refer a format to the concepts, algorithms of actions, methods and so forth. However the Anglo-Saxon legal system countries limit but do not completely deny the attempts of formats' protection through such doctrines as "scenes a fair", "doctrines of merge", "the test of abstraction and filtration".

Considering the fact that Supreme courts of the leading countries in the field of Intellectual Property Law provide legal protection to a format through the positive approach, we give our preference to it and we consider it reasonable to apply this approach on the international level and to unify the respective concepts. Positive attempts of protection in the Common Law countries are embodied in the concepts of a format as dramatic work, a format as a Copyright Law object and the so-called "spine idea". Concepts of the Romano-Germanic legal system theoreticians are more diverse. Thus the French and English authors assert the concept of a hybrid object, the Russian theoreticians have elaborated the concepts of "a synthetic object" and "a complex object". We find it reasonable that for the purpose of legal definiteness and unification of legal regimes of the countries it is expedient to give preference to the concept of a complex object of IP Law.

Summarizing all the above-mentioned, the television format is a vulnerable object as to its legal regulation due to inconsistent judicial practice. In most cases Supreme Courts provide definitions of a television format, describe its elements where it is recognized as an IP Law object. Considering the fact that Romano-Germanic legal system has normative legal acts as the main source of law it is important to regulate this problem at the legislative level. Improvements of the legislation and ensuring appropriate hearing of cases from intellectual property right will contribute to the development of a turn of objects of the IP Law. Formats consist of diverse elements part of which is protected by Copyright Law and the rest is not. Applying various legal regimes to each component of a TV format separately will continue to generate ambiguity and inconsistency in practice. It is reasonable to consider a format as a uniform complex object and to apply the unified protection for this product.

\section{References}

1) Alberts W. (2019) Problematic aspects of copyright protection for television show formats. Without prejudice. URL:https://www.withoutprejudice.co.za/free/article/6698/view

2) Banner universal motion pictures Ltd v Endemol shine group Ltd \& Anor (2017) England and Wales High Court (Chancery Division) URL:https://www.casemine.com/judgement/uk/5b2897fa2c94e06b9e19e91c 
3) Clark D. (2016) Intellectual Property Law Hybridization.87 U. Colo. L. Rev. 65. URL:https://digitalcommons.law.byu.edu/cgi/viewcontent.cgi?article $=1094 \&$ context $=$ faculty sc holarship

4) Dozorcev V.A. (2003) Intellectual rights: definition, system, task for codification. Moscow. p.144-146 URL: http://telecomlaw.ru/young res/Doz inrigth.pdf

5) Fink v Goodson-Todman Enterprises Ltd (1970) Docket No. 33731. URL:https://casetext.com/case/ fink-v-goodson-todman-enterprises-ltd

6) Green $\mathrm{v}$ Broadcasting Corp of New Zealand (1989) R.P.C. 469 (N.Z.C.A.) URL: https://academic.oup.com/rpc/article-abstract/106/22/700/1588698/GREEN-vBROADCASTING-CORPORATION-OF-NEW-ZEALAND? redirectedFrom=fulltext

7) Lindenfeld G. (2016) Ptotecting TV Show Formats: lessons from NBC`s timeless. Fordham. Intellectual property, Media \& Entertainment journal. URL: http://www.fordhamiplj.org/2016/10/26/protecting-tv-show-formats-nbcs-timeless/

8) Moran A. (2009) New Flows in Global TV. Intellect Ltd. URL:https://books.google.com.ua/books?id=W7mrDwAAQBAJ\&pg=PA138\&lpg=PA138\&dq = survive+vs. + big + brother+ netherlands $+2003 \&$ source $=$ bl\&ots $=1 \mathrm{xznKlcU} 2 \mathrm{Q} \& \mathrm{sig}=\mathrm{ACfU} 3 \mathrm{U} 3 \mathrm{Tt}$ Ujr5bVY1h1IcZcAKYdkT6rzPA\&hl=uk\&sa $=$ X\&ved=2ahUKEwjCwIL5yqjinAhWxioKHVbTBOcQ6AEwAHoECAUQAQ\# ${ }_{\mathrm{v}}=$ onepage $\& \mathrm{q}=$ survive $\% 20 \mathrm{vs} . \% 20 \mathrm{big} \% 20 \mathrm{brother} \% 20$ netherlands $\% 202003 \& \mathrm{f}=$ false

9) Novicova A. (2010) Hybridization is the main charter of a TV format. URL:https://vestnik.journ.msu.ru/books/2010/6/gibridnost-kak-opredelyayushchiy-priznaktelevizionnogo-formata/

10) Rendas T. (2015) European Intellectual Property Review. Volume 37. Issue 1. p.40

11) Scientifically practical Commentary Civil Code (2003). The official website of the Verkhovna Rada of Ukraine. URL: http://zakon2.rada.gov.ua/laws/show/435-15/page5

12) The TRIPS Agreement (1995). URL: https://www.wto.org/english/docs e/legal e/27-trips 03 e.htm

13) Zhylinkova O. (2008) Complex work - new terminology. Law practice № 36. Ukraine.

14) Zhylinkova O. Legal protection of a television format as an object of intellectual property rights. Pravnyk. Ukraine. URL: http://www.pravnuk.info/urukrain/1269-pravova-oxoronatelevizijnogo-formatu-yak-ob-yekta-prava-intelektualno-vlasnosti.html 